\title{
PHAGOCYTOSIS AND KILLING OF BACTERIA IN AEROBIC AND ANAEROBIC CONDITIONS
}

\author{
H. R. Ingham, Penelope R. Sisson, \\ Rosemary L. Middleton, H. K. Narang, A. A. Codd, \\ AND J. B. SELKON
}

Regional Public Health Laboratory, General Hospital, Newcastle upon Tyne NE4 6BE

\section{Plates XXIV-XXVII}

\begin{abstract}
Summary. Phagocytosis and intracellular killing of several facultative anaerobes were observed in aerobic and anaerobic conditions. The presence of anaerobes affected these processes. Bacteroides asaccharolyticus and $B$. fragilis were killed by phagocytes only at bacterial concentrations less than $1 \times 10^{7} \mathrm{cfu} / \mathrm{ml}$; at higher concentrations of the anaerobes, killing of $B$. fragilis and concomitant facultative anaerobes was inhibited. This effect appeared to be due to an interaction, in appropriate reducing conditions, between anaerobe and serum, which allowed engulfment of organisms by phagocytes but markedly impaired intracellular killing.
\end{abstract}

\section{INTRODUCTION}

The increasing acceptance of the importance of non-sporing obligate anaerobes in human infections has stimulated investigations of the pathogenic mechanisms involved. One area of research concerns the role of the phagocyte but investigations by different workers have produced disparate results. McRipley and Sbarra (1967) reported normal phagocytosis in anaerobic conditions, but impaired killing of some species of ingested bacteria. Mandell (1974) also observed that only some species of bacteria were killed by phagocytes in anaerobic conditions. Bjornson and Bjornson (1978), when studying the phagocytosis of obligate anaerobes, found that Bacteroides fragilis and $B$. thetaiotaomicron were killed in anaerobic conditions. Other workers testing the effect of obligate anaerobes on the phagocytic process in aerobic conditions (Ingham et al., 1977; Tofte et al., 1980) found that obligate anaerobes inhibit their own phagocytosis and killing, and that of concomitant facultative anaerobes. This seems to be a specific property of obligate anaerobes because it was not produced by facultative anaerobes. To clarify these various reports, we have extended our original observations by examining phagocytosis in anaerobic as well as aerobic conditions. 


\section{MATERIALS AND METHODS}

Bacteria. All bacteria used in this study were isolated from clinical material cultured in this laboratory, with the exception of Pseudomonas aeruginosa strain NCTC10662, which was supplied by the National Collection of Type Cultures, Colindale, London NW9 5HT. Aerobic organisms were identified by reference to Cowan (1974), and obligate anaerobes by the scheme described by Duerden et al. (1976) and by examination of their API ZYM patterns (Tharagonnet et al., 1977). Anaerobic cultures were incubated for at least $48 \mathrm{~h}$ at $37^{\circ} \mathrm{C}$ in an anaerobic jar with a cold catalyst, in an atmosphere of $90 \% \mathrm{H}_{2}$ and $10 \% \mathrm{CO}_{2}$. The attainment and maintenance of anaerobiosis was monitored by the inclusion in every jar of a nutrient-agar plate inoculated with $P$. aeruginosa strain NCTC10662, the growth of which indicated unsatisfactory anaerobiosis.

Preparation of phagocytes. Venous blood was obtained from inpatients undergoing venepuncture for other investigations and who were not receiving antibacterial agents. Phagocytes were prepared by sedimenting $10 \mathrm{ml}$ of heparinised blood with $2 \mathrm{ml}$ of a solution of dextran $5 \%(\mathrm{w} / \mathrm{v})$ in physiological saline. Phagocytes were washed once in Hanks's balanced salt solution (HBSS) at $p \mathrm{H} \mathrm{7}$, counted in a haemocytometer and resuspended in HBSS at $2 \times 10^{6}$ cells $/ \mathrm{ml}$. No attempt was made to prepare pure suspensions of polymorphonuclear leucocytes.

Preparation of bacteria. An isolate of Proteus mirabilis which was phagocytosed and killed in vitro was selected as an indicator strain in the study of inhibition of these processes by obligate anaerobes. The indicator strain was grown overnight in Hartley's broth prepared in this laboratory from Oxoid Peptone and Lab-Lemco (Oxoid), washed thrice in physiological saline and suspended in saline at a density of $5 \times 10^{7}$ organisms $/ \mathrm{ml}$, determined in a Unigalvo type-20 nephelometer.

All bacteria to be tested for their capacity to inhibit phagocytosis and killing of the indicator strain, referred to as challenge organisms, were grown for $48 \mathrm{~h}$ in Bacto Cooked Meat Medium (CMM), (Difco), supplemented with menadione $1 \mathrm{mg} / \mathrm{L}$. The broth cultures from this medium were used directly, without washing, unless otherwise indicated. After the numbers of bacteria had been determined nephelometrically, appropriate dilutions of challenge suspensions were prepared in broth from CMM (CMMB) to give $c .10^{8}$ organisms $/ \mathrm{ml}$. All controls contained uninoculated CMMB supplemented with menadione $1 \mathrm{mg} / \mathrm{L}$.

Phagocytosis. The phagocytic system used was a modification of that described by Biggar (1975), and has been used before (Ingham et al., 1977). Each sterile $75 \times 12.5-\mathrm{mm}$ glass tube contained $0.5 \mathrm{ml}$ of the phagocyte suspension, $0.1 \mathrm{ml}$ of normal serum (on each occasion from the same patient as the phagocytes), $0.3 \mathrm{ml}$ of HBSS, $0.1 \mathrm{ml}$ of the challenge strain and $0.1 \mathrm{ml}$ of the indicator strain. Appropriate controls for serum, phagocytes, challenge and indicator strains were included in every experiment and all experiments were performed on at least three separate occasions. The tubes were rotated at $5 \mathrm{rpm}$, aerobically or anaerobically, at $37^{\circ} \mathrm{C}$ for 5 $\mathrm{h}$, in equipment purpose-built by our Department of Medical Physics. For anaerobic incubation, the tubes were placed in a Perspex rack inside an anaerobic jar which was then mounted on the rotation apparatus.

Because the 5-h incubation was too short to allow the use of $P$. aeruginos $a$ as a biological control of anaerobiosis, this was monitored by the inclusion in anaerobic jars of CMMB inoculated with $B$. fragilis and containing metronidazole at a final concentration of $5 \mathrm{mg} / \mathrm{L}$. Satisfactory anaerobiosis, necessary for the activity of metronidazole against $B$. fragilis (Tally $e t$ $a l ., 1978$ ), was indicated by a 1000 -fold decrease in the viable count during the 5 -h period of incubation.

Viable counts were performed on the initial inoculum of the indicator strain and on all tubes after incubation by making tenfold dilutions in distilled water and transferring $0.001 \mathrm{ml}$ with a fused platinum-iridium loop (Johnson Matthey Metals Ltd) onto MacConkey Agar (Oxoid). Viable counts of anaerobic challenge strains were done, by the same method, after anaerobic incubation on agar containing defibrinated horse blood $5 \%(\mathrm{v} / \mathrm{v})$ and nalidixic acid $50 \mathrm{mg} / \mathrm{L}$, to inhibit selectively the growth of gram-negative facultative anaerobes, (Ingham et al., 1978). Smears were prepared from all tubes and stained by the Gram technique. For counting of extracellular and intracellular organisms $1-\mathrm{ml}$ samples of the reaction mixtures were centrifuged at $150 \mathrm{~g}$ for $3 \mathrm{~min}$. The supernatants were then removed and viable counts made as above. The 
deposited phagocytes were washed thrice with HBSS and resuspended in distilled water to a final volume of $1 \mathrm{ml}$. After an interval of $5 \mathrm{~min}$ for lysis of the white cells, viable counts were performed as above.

Redox potential and $\mathrm{pH}$ measurement. Redox potential was measured with a Beckman 3500 digital $p \mathrm{H}$ meter and a platinum-spade combination electrode, supplied by Russell Laboratory $p \mathrm{H}$ Electrodes, Auchtermuchty, Fife. The electrode was standardised against ferrous-ferric ammonium sulphate $0 \cdot 1 \mathrm{M}$ in $1 \mathrm{M} \mathrm{H}_{2} \mathrm{SO}_{4}$, which has a redox potential of $476 \mathrm{mV}$ (Light, 1972). All $p \mathrm{H}$ measurements were made with the same machine and a combination $p \mathrm{H}$ electrode.

Electronmicroscopy. Cell samples for electronmicroscopy (EM) were pelleted by centrifugation and washed in phosphate-buffered saline (PBS) (Oxoid). Enough material to give approximately $1 \mu \mathrm{l}$ of packed cells was resuspended in a small volume of PBS and centrifuged in a polyethylene embedding capsule at $150 \mathrm{~g}$ for $10 \mathrm{~min}$. After removal of the supernate the pellet was fixed in situ with glutaraldehyde $4 \%(\mathrm{w} / \mathrm{v})$ for $1 \mathrm{~h}$, washed with three changes of PBS and post-fixed with Dalton's osmic acid $1 \%(\mathrm{w} / \mathrm{v})$ for $1 \frac{1}{2} \mathrm{~h}$. After further washing, the pellet was dehydrated and embedded in epon and polymerised in the usual manner. The resulting blocks were processed in the same way as for tissue fragments.

Statistical test. The chi-square test with Yates's correction was used.

\section{RESULTS}

All numerical data presented are from single experiments but are representative of those obtained on three or more occasions.

\section{Phagocytosis and killing of bacteria in aerobic and anaerobic conditions}

In outline, incubation of several facultative and obligate anaerobes, at a final concentration of $c .5 \times 10^{6} \mathrm{cfu} / \mathrm{ml}$, with serum and phagocytes for $5 \mathrm{~h}$ at $37^{\circ} \mathrm{C}$ resulted in a decrease in the viable count to $c .10^{3} \mathrm{cfu} / \mathrm{ml}$ in aerobic and to c. $10^{4} \mathrm{cfu} / \mathrm{ml}$ in anaerobic conditions (table I). When the concentration of facultative anaerobes was increased to $c .1 \times 10^{7} \mathrm{cfu} / \mathrm{ml} \mathrm{killing} \mathrm{still} \mathrm{occurred} \mathrm{but}$ there was a proportionate rise in the final count in aerobic and anaerobic conditions. At a concentration of $c .1 \times 10^{7} \mathrm{cfu} / \mathrm{ml} \mathrm{B}$. fragilis was no longer killed. The same effect was obtained with $B$. asaccharolyticus in anaerobic

TABLE I

Viable counts of different species of bacteria, after incubation for $5 \mathrm{~h}$ with phagocytes and serum in anaerboic and aerobic conditions

\begin{tabular}{l|rrrrr}
\hline \multicolumn{1}{c|}{ Bacteria } & \multicolumn{2}{c}{$\begin{array}{c}\text { Viable count in } \\
\text { aerobic conditions (cfu/ml) }\end{array}$} & \multicolumn{2}{c}{$\begin{array}{c}\text { Viable count in } \\
\text { anaerobic conditions (cfu/ml) }\end{array}$} \\
${$\cline { 2 - 3 }$} }$ & At $5 \mathrm{~h}$ & & Initial & At $5 \mathrm{~h}$ \\
\hline Proteus mirabilis & $8 \times 10^{6}$ & $9 \times 10^{3}$ & & $8 \times 10^{6}$ & $2 \times 10^{4}$ \\
Escherichia coli & $5 \times 10^{5}$ & $<1 \times 10^{3}$ & & $2 \times 10^{7}$ & $4 \times 10^{4}$ \\
Klebsiella aerogenes & $1 \times 10^{7}$ & $3 \times 10^{4}$ & & $2 \times 10^{7}$ & $4 \times 10^{4}$ \\
Streptococcus faecalis & $1 \times 10^{6}$ & $7 \times 10^{2}$ & & $7 \times 10^{7}$ & $5 \times 10^{4}$ \\
Bacteroides asaccharolyticus & $1 \times 10^{6}$ & $<1 \times 10^{3 *}$ & & $1 \times 10^{6}$ & $<1 \times 10^{3}$ \\
B. fragilis & $4 \times 10^{6}$ & $1 \times 10^{3}$ & & $3 \times 10^{6}$ & $1 \times 10^{3}$ \\
\hline
\end{tabular}

* The viable count of $B$. asaccharolyticus in the absence of phagocytes and serum was reduced to $<1 \times 10^{3}$ after aerobic incubation for $5 \mathrm{~h}$. 
conditions, but in air the viable count of this strain was reduced in the absence of serum and phagocytes due, presumably, to the toxic effect of oxygen.

\section{Effect of obligate anaerobes on phagocytosis and killing of facultative anaerobes in aerobic and anaerobic conditions}

The results of these experiments were similar in anaerobic and aerobic conditions and will be described together except where stated otherwise.

In the presence of $B$. fragilis c. $5 \times 10^{6} \mathrm{cfu} / \mathrm{ml}$, killing of facultative anaerobes in the phagocytic system was not impaired. When the concentration of the anaerobe was increased to $c .1 \times 10^{7} \mathrm{cfu} / \mathrm{ml}$, killing of the indicator strain was inhibited (table II). This effect was still apparent when the addition

TABLE II

Effect of different inocula of Bacteroides fragilis on phagocytic killing in aerobic conditions

\begin{tabular}{|c|c|c|c|c|}
\hline \multirow[b]{2}{*}{ Bacteria } & \multicolumn{2}{|c|}{$\begin{array}{c}\text { Viable count of } \\
P . \text { mirabilis }(\mathrm{cfu} / \mathrm{ml})\end{array}$} & \multicolumn{2}{|c|}{$\begin{array}{l}\text { Viable count of } \\
\text { B. fragilis }(\mathrm{cfu} / \mathrm{ml})\end{array}$} \\
\hline & Initial & At $5 \mathrm{~h}$ & Initial & At $5 \mathrm{~h}$ \\
\hline \multirow{3}{*}{$\begin{array}{l}\text { Proteus mirabilis } \\
P . \text { mirabilis }+ \text { Bacteroides } \\
\text { fragilis (undiluted)* } \\
P . \text { mirabilis }+B . \text { fragilis } \\
\text { (diluted } 1 \text { in } 10)^{*}\end{array}$} & $8 \times 10^{6}$ & $6 \times 10^{4}$ & $\ldots$ & $\ldots$ \\
\hline & $8 \times 10^{6}$ & $1 \times 10^{8}$ & $4 \times 10^{7}$ & $5 \times 10^{6}$ \\
\hline & $8 \times 10^{6}$ & $1 \times 10^{5}$ & $4 \times 10^{6}$ & $<1 \times 10^{3}$ \\
\hline
\end{tabular}

* An overnight culture of B. fragilis Bacto Cooked Meat Medium was used undiluted or diluted 1 in 10 , as shown in parentheses, in broth from Bacto Cooked Meat Medium.

of the anaerobe was delayed by $1 \mathrm{~h}$ after the start of the experiment, but not after this time. The inhibitory activity of the obligate anaerobe in this system was cell-associated because it was not apparent in the cell-free supernate of centrifuged suspensions of cultures of these organisms grown in CMM.

Inhibition of phagocytic killing by $B$. asaccharolyticus was observed with 10 strains of $P$. mirabilis, four strains of Escherichia coli, one strain of Klebsiella atlantae and seven strains of Streptococcus faecalis. At a concentration of $1 \times 10^{7} \mathrm{cfu} / \mathrm{ml}$ none of these strains inhibited phagocytic killing of other facultative anaerobes in this system, nor did other strains of these species, which were themselves not killed in the system used.

Factors affecting inhibition of phagocytic killing by obligate anaerobes. These studies, except where otherwise specified, were made with $P$. mirabilis and $B$. asaccharolyticus. B. asaccharolyticus failed to inhibit killing of $P$. mirabilis when the initial inoculum of the latter was less than $5 \times 10^{6} \mathrm{cfu}$. In these circumstances, serum in the absence of phagocytes either prevented multiplication of the indicator strain or caused a reduction in the viable count after $5 \mathrm{~h}$. However, when serum was pre-incubated with the anaerobe for $1 \mathrm{~h}$ at $37^{\circ} \mathrm{C}$ and the organisms removed by centrifugation, the serum no longer supported phagocytic killing in the system. Phagocytic killing did occur when 
the pre-treated serum was mixed with an equal volume of fresh, but not heat-inactivated serum $\left(58^{\circ} \mathrm{C}\right.$ for $\left.20 \mathrm{~min}\right)$. The latter exhibited little activity in the system itself.

Effect of redox potential. B. asaccharolyticus grown in CMM, centrifuged and resuspended after washing three times, in either Hartley's broth or saline, no longer inhibited killing of $P$. mirabilis unless ascorbic acid $(0 \cdot 1 \% \mathrm{w} / \mathrm{v})$ was present as a reducing agent. Such washed deposits resuspended in CMMB were inhibitory. The redox potentials of the complete phagocytic system with the challenge organism contained in different media are shown in table III which indicates that the various reducing agents did not cause a major reduction in the redox potential.

TABLE III

Redox potentials of the phagocytic system with challenge organisms added in different media

\begin{tabular}{|c|c|c|}
\hline Challenge organism & $\begin{array}{l}\text { Redox } \\
\text { potential } \\
(\mathrm{mV})\end{array}$ & $p \mathrm{H}$ \\
\hline Bacteroides asaccharolyticus from 2-day CMMB & -62 & $7 \cdot 50$ \\
\hline B. asaccharolyticus washed*, resuspended in CMMB & 80 & $7 \cdot 51$ \\
\hline B. asaccharolyticus washed, resuspended in Hartley's broth & 105 & $7 \cdot 46$ \\
\hline $\begin{array}{l}\text { B. asaccharolyticus washed, resuspended in Hartley's broth } \\
+1 \% \text { ascorbic acid }\end{array}$ & 52 & $6 \cdot 33$ \\
\hline $\begin{array}{l}\text { B. asaccharolyticus washed, resuspended in physiological } \\
\text { saline }\end{array}$ & 180 & $7 \cdot 68$ \\
\hline $\begin{array}{l}\text { B. asaccharolyticus washed, resuspended in physiological } \\
\text { saline }+1 \% \text { ascorbic acid }\end{array}$ & 94 & \\
\hline$B$. fragilis grown in Hartley's broth anaerobically & -40 & $7 \cdot 41$ \\
\hline
\end{tabular}

$\mathrm{CMMB}=$ Bacto Cooked Meat Medium broth.

* Deposit from the broth of CMMB was washed three times in physiological saline.

Effect of heat. The inhibitory activity of $B$. asaccharolyticus was not impaired by autoclaving at $115^{\circ} \mathrm{C}$ for $20 \mathrm{~min}$. The effect of heat on the inhibitory activity of $B$. fragilis varied; some strains were still inhibitory after autoclaving as described, some lost this activity after heating at $100^{\circ} \mathrm{C}$ for 10 $\mathrm{min}$ and others after exposure to $58^{\circ} \mathrm{C}$ for $20 \mathrm{~min}$.

Effect of metronidazole. When metronidazole was added, at a final concentration of $10 \mathrm{mg} / \mathrm{L}$, to an overnight culture of $B$. asaccharolyticus in $\mathrm{CMM}$, which was then further incubated at $37^{\circ} \mathrm{C}$ for $24 \mathrm{~h}$, an undiluted suspension of the anaerobe failed to inhibit phagocytic killing of $P$. mirabilis. In contrast the same final concentration of metronidazole added to the phagocytic system, incubated anaerobically, had no effect on the inhibitory activity of $B$. asaccharolyticus.

\section{Microscopical observations}

Very few $P$. mirabilis were visible in gram-stained smears prepared from the phagocytic system after incubation for $5 \mathrm{~h}$ at $37^{\circ} \mathrm{C}$ in the absence of $B$. 
TABLE IV

Effect of heat inactivation $\left(58^{\circ} \mathrm{C}\right.$ for $\left.20 \mathrm{~min}\right)$ of serum and the presence of Bacteroides asaccharolyticus on killing of Proteus mirabilis by phagocytes

\begin{tabular}{l|llc}
\hline \multicolumn{1}{c|}{ Bacteria } & \multicolumn{1}{c}{ Serum } & \multicolumn{2}{c}{$\begin{array}{c}\text { Viable count of } \\
\text { B. fragilis }(\mathrm{cfu} / \mathrm{ml})\end{array}$} \\
\cline { 2 - 4 } & & Initial & At $5 \mathrm{~h}$ \\
\hline Proteus mirabilis & Normal & $1 \times 10^{7}$ & $6 \times 10^{3}$ \\
P. mirabilis + Bacteroides asaccharolyticus & Normal & $1 \times 10^{7}$ & $3 \times 10^{6}$ \\
$P$. mirabilis & Heat inactivated & $1 \times 10^{7}$ & $6 \times 10^{6}$ \\
$P$. mirabilis + B. asaccharolyticus & Heat inactivated & $1 \times 10^{7}$ & $5 \times 10^{8}$ \\
$P$. mirabilis control* & $\ldots$ & $1 \times 10^{7}$ & $7 \times 10^{8}$ \\
\hline
\end{tabular}

* No phagocytes or serum.

asaccharolyticus (fig. 1). By contrast, in the presence of the anaerobe, or serum pre-treated with the anaerobe, many $P$. mirabilis were seen, some between phagocytes and many others in close association with the cells (fig. 2). Large numbers of intracellular and extracellular bacteria were observed when the anaerobe alone was present in the system. Examination of smears prepared from the phagocytic system with heat-inactivated serum but lacking the anaerobe, also demonstrated an accumulation of $P$. mirabilis within phagocytes (fig. 3). Addition of the anaerobe to the same system resulted in an increase in the number of intracellular $P$. mirabilis (fig. 4). In both instances there was impaired killing of the indicator strain but this was more marked in the presence of the anaerobe (table IV).

Electronmicroscopy of thin sections prepared from the phagocytic system containing $P$. mirabilis alone indicated that there were never more than three bacteria per cell. The organisms were either surrounded by host-cell membrane or in a vacuole and active bacterial cytolysis was apparent at various stages (fig. 5). In the additional presence of the anaerobe, occasional bacteria were seen surrounded by a host-cell membrane or in a vacuole but most of the organisms were intracytoplasmic (fig. 6). In some instances there were as many as 10 bacteria per cell. Moreover, many more polymorpho-

\section{TABLE V}

Electronmicroscopic counts in thin sections of the numbers of polymorphonuclear leucocytes containing bacteria after incubation of Proteus mirabilis for $5 \mathrm{~h}$ aerobically with serum in the presence and absence of Bacteroides asaccharolyticus

\begin{tabular}{l|ccc}
\hline & \multicolumn{3}{|c}{ Number of polymorphonuclear leucocytes } \\
\cline { 2 - 4 } Bacteria & $\begin{array}{l}\text { containing } \\
\text { bacteria }\end{array}$ & $\begin{array}{c}\text { not containing } \\
\text { bacteria }\end{array}$ & $\begin{array}{c}\text { counted } \\
\text { (total) }\end{array}$ \\
\hline $\begin{array}{l}\text { Proteus mirabilis } \\
\text { P. mirabilis+ } \\
\text { Bacteroides asaccharolyticus }\end{array}$ & 59 & 116 & 175 \\
\hline
\end{tabular}




\section{ANAEROBES AND PHAGOCYTOSIS}
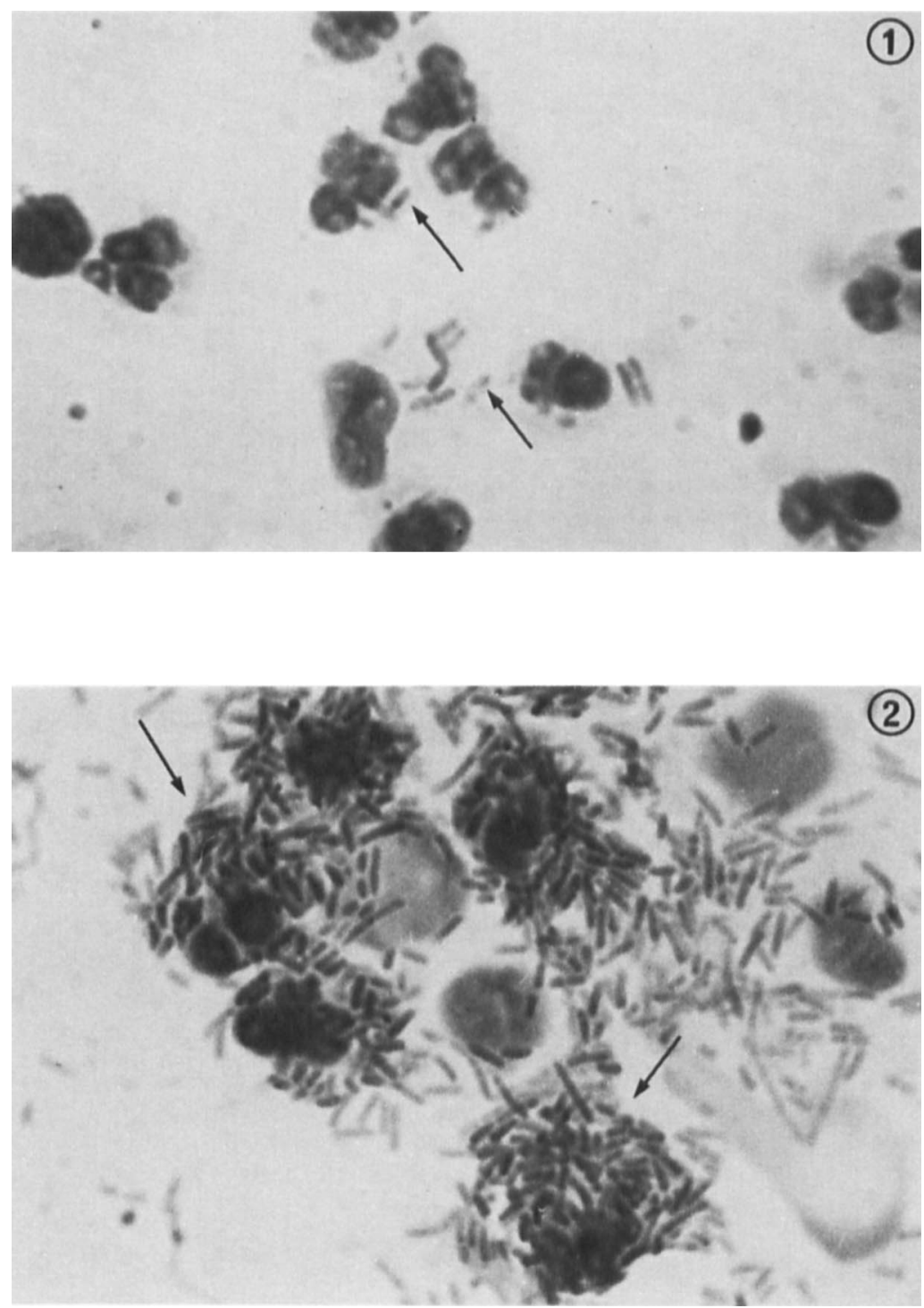

Fig. 1. Phagocytosis of a pure culture of $P$. mirabilis showing polymorphonuclear leucocytes (PMNL) containing few bacteria (arrows). Aerobic incubation. Gram's stain. $\times 1080$.

FIG. 2. Phagocytosis of a mixture of P. mirabilis and B. asaccharolyticus showing large numbers of Proteus associated with PMNL. Aerobic incubation. Gram's stain. $\times 1080$. 
ANAEROBES AND PHAGOCYTOSIS
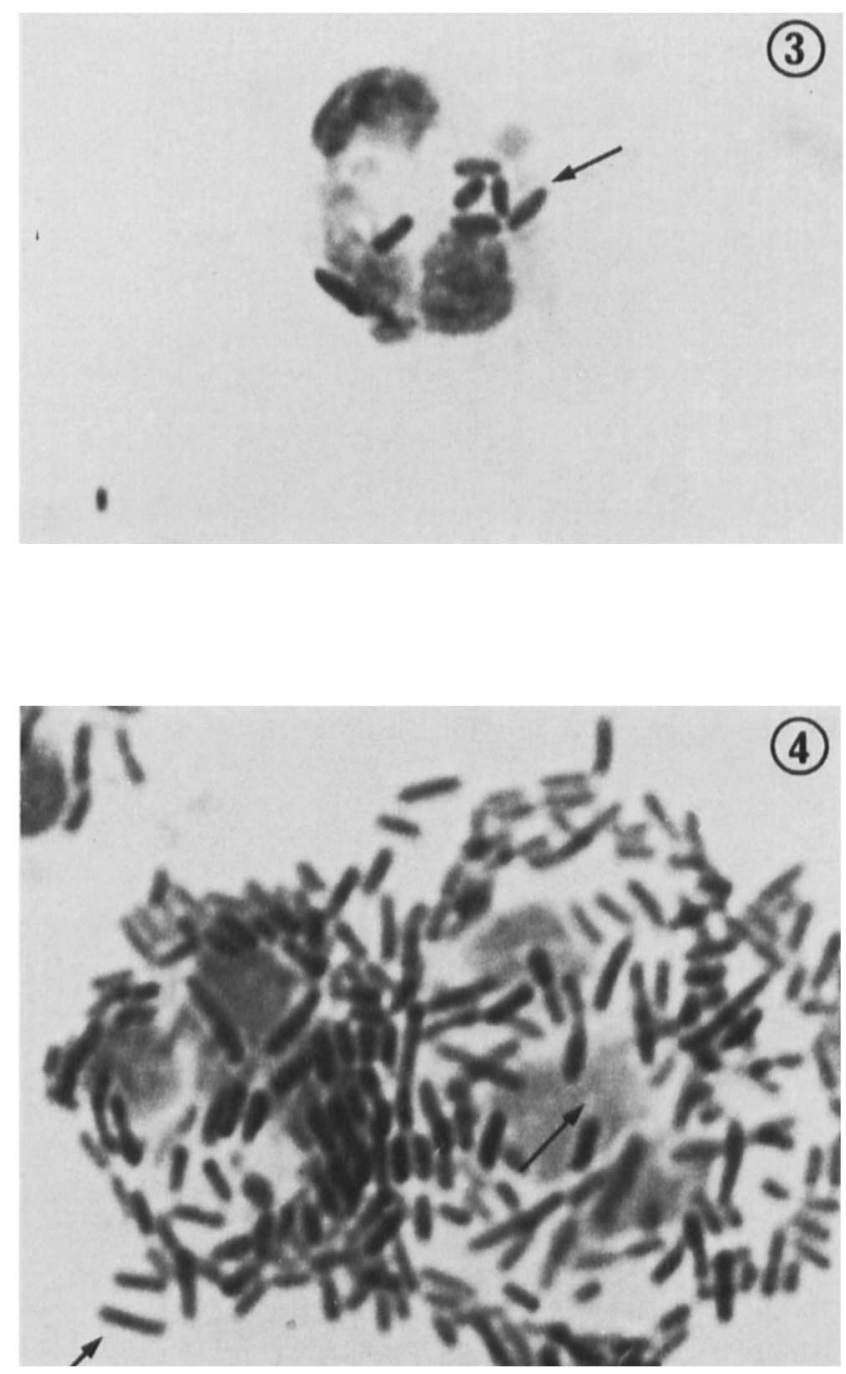

FIG. 3. Effect of heat inactivation of serum on the phagocytosis of a pure culture of $P$. mirabilis and showing few bacteria within PMNL (arrow). Aerobic incubation. Gram's stain. $\times 1200$.

FIG. 4. Effect of heat inactivation of serum on phagocytosis of a mixture of $P$. mirabilis and $B$. asaccharolyticus and showing more of the former extracellularly and within PMNL (arrows). Aerobic incubation. Gram's stain. $\times 1200$. 


\section{ANAEROBES AND PHAGOCYTOSIS}

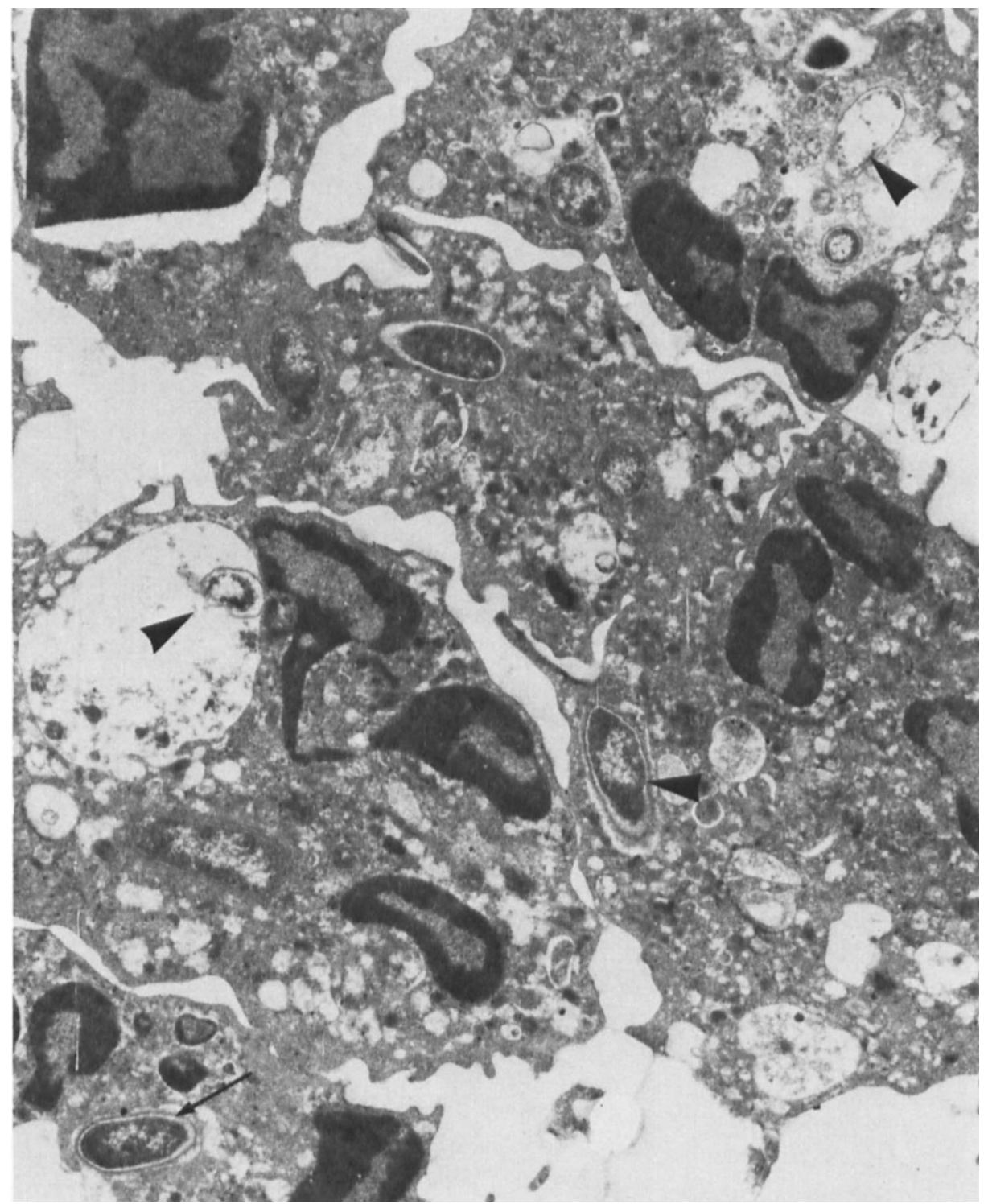

FIG. 5 Thin section of PMNL after contact with a pure culture of $P$. mirabilis showing bacteria surrounded by host-cell membrane (arrow) or in vacuoles in various stages of cytolysis (arrowheads). EM. $\times 9000$. 


\section{ANAEROBES AND PHAGOCYTOSIS}

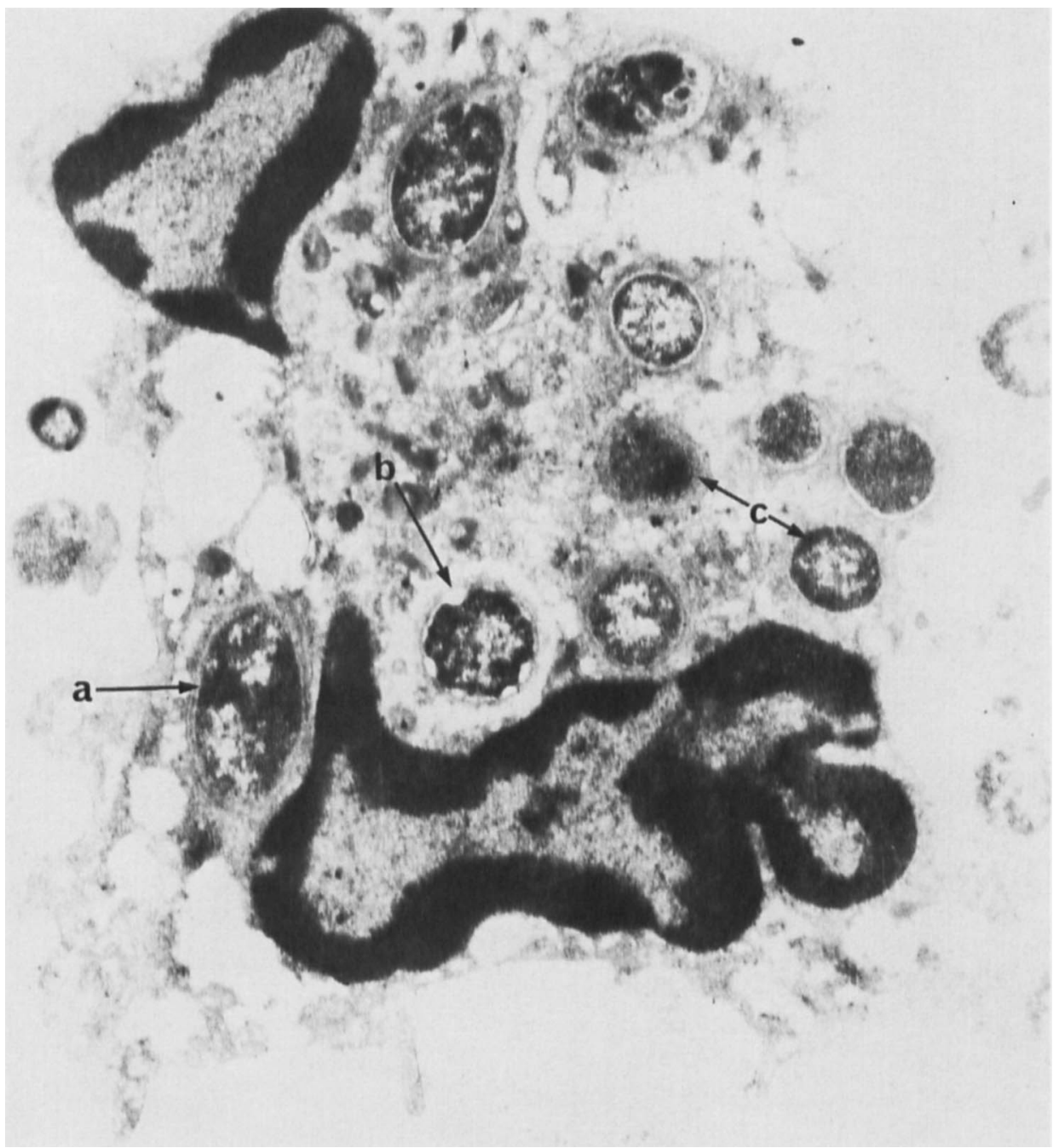

FIG. 6. Thin section of PMNL after contact with a mixture of $P$. mirabilis and $B$. asaccharolyticus showing bacteria surrounded by host-cell membrane (a), or in vacuoles (b), or intracytoplasmic (c). EM. $\times 18000$. 
nuclear leucocytes contained bacteria than in the system containing $P$. mirabilis alone (table V); the difference between these was highly significant $(p<0.001)$. These microscopical observations in the complete system containing the anaerobe were confirmed by viable counts of the extracellular and cell-associated $P$. mirabilis which were $3 \times 10^{6} \mathrm{cfu} / \mathrm{ml}$ and $4.4 \times 10^{7} \mathrm{cfu} / \mathrm{ml}$ respectively.

\section{Discussion}

In the present study, phagocytosis and killing of facultative anaerobes occurred in aerobic and in anaerobic conditions. Phagocytic killing of obligate anaerobes also occurred in these conditions but only with inocula of less than $10^{7} \mathrm{cfu}$. This observation is in agreement with previous reports by several workers, all of whom used human serum and phagocytes at a concentration of $5 \times 10^{6} / \mathrm{ml}$ (Casciato et al., 1975; Bjornson, Altemeier and Bjornson, 1976; Bjornson and Bjornson, 1978). The largest inoculum of anaerobes used by these workers was $5 \times 10^{6} \mathrm{cfu}$. In contrast, Tofte et al. (1980) using B. fragilis, B. melaninogenicus ss melaninogenicus, B. thetaiotaomicron and $B$. vulgatus, at a concentration of $10^{8} \mathrm{cfu} / \mathrm{ml}$, reported some phagocytosis and killing of these organisms, but observed that $B$. fragilis and $B$. melaninogenicus both inhibited killing of a strain of E. coli. Using $\left[{ }^{3} \mathrm{H}\right]$ thymidine-labelled $E$. coli they observed impaired opsonisation in the presence of anaerobes. Further studies of the kinetics of opsonisation of these three organisms indicated that in $10 \%$ human serum the anaerobes were more rapidly opsonised than $E$. coli. It was considered that the anaerobes competed with $E$. coli for opsonins, thereby inhibiting phagocytosis.

The results reported by Tofte et al. (1980) confirm our observation that obligate anaerobes inhibit killing of facultative anaerobes (Ingham et al., 1977) but the mechanism suggested differs in some respects from that postulated in the present work. Both studies indicate that the effect of the anaerobes on phagocytosis and killing depends primarily on an interaction between these organisms and serum. Tofte et al. (1980) believe that this is mediated by a heat-labile opsonin via the classical complement pathway.

Our observation that the impaired capacity of the phagocyte to kill facultative anaerobes in the presence of serum pre-treated with obligate anaerobes was restored by the addition of fresh but not by heat-treated serum, indicates that the anaerobes remove a heat-labile serum component essential for intracellular killing. Moreover, the observation that in the system containing heat-treated serum the addition of the anaerobe increased the number of intracellular $P$. mirabilis, and impaired killing of the latter, indicates that the anaerobe also interfered with the activity of a heat-stable serum component concerned with intracellular killing. Whereas Tofte et al. (1980) demonstrated impaired phagocytosis, the present study indicated that ingestion of facultative anaerobes by phagocytes proceeded normally in the presence of anaerobes at a final concentration of $10^{7} \mathrm{cfu} / \mathrm{ml}$ or more, but killing was impaired. This suggests that inhibition of killing results from interference 
with some intracellular event consequent upon the interaction of anaerobes and serum.

The difference between the findings of the present study and those of Tofte et al. (1980) may be explained by the fact that in the latter study the anaerobes were grown in anaerobic conditions in Todd-Hewitt broth, washed and resuspended in PBS. Studies in this laboratory showed that when such a suspension was used, inhibition of killing of the indicator strain did not occur. We were, however, able to demonstrate inhibition of killing of the indicator strain with suspensions of anaerobes in saline containing ascorbic acid $0 \cdot 1 \%$. Because the redox potentials of these various systems did not differ substantially it seems likely that the critical factor was lowering of oxygen tension, which it is known may vary independently of redox potential (Walden and Hentges, 1975). The present study also indicates that there must be suitable conditions at the time the anaerobes are added to the system. Thus even when the test was done in anaerobic conditions, with the anaerobe resuspended in Hartley's broth, inhibition of killing of facultative anaerobes required the presence of $0.1 \%$ ascorbic acid as a reducing agent. Moreover, metronidazole interfered with the inhibitory activity of the anaerobes only, if pre-incubated with them before addition to the system.

The experimental design of this work provided conditions that are comparable to the milieu of naturally occurring abscesses. Thus Weinstein et al. (1975), in a study of experimental intra-abdominal sepsis in Wistar rats, reported that $\boldsymbol{B}$. fragilis and Fusobacterium varium were present in abscesses in 10 animals at mean concentrations of $10^{8.8} / \mathrm{ml}$ and $10^{8.6} / \mathrm{ml}$ respectively. Obligate anaerobes are present in human faeces at concentrations 100 -fold higher than in experimental abscesses (Gorbach and Bartlett, 1974). Thus when the integrity of the large bowel is breached, as the result of disease or trauma, phagocytes encounter more obligate anaerobes than are usually employed in in-vitro studies of phagocytosis. It has also been shown that abscesses have a low oxygen content. Hays and Mandell (1974), studying experimental abscesses in rats due to Staphylococcus aureus and E. coli, observed that the $\mathrm{pO}_{2}$ of pus aspirated from 7-day-old lesions was $8 \mathrm{~mm} \mathrm{Hg}$ and $12 \mathrm{~mm} \mathrm{Hg}$ respectively.

The failure of previous workers to demonstrate inhibition of phagocytic killing by obligate anaerobes (Casciato et al., 1975; Bjornson, Altemeier and Bjornson, 1976; Bjornson and Bjornson, 1978) was almost certainly due to the small inocula of obligate anaerobes used and inappropriate reducing conditions in the phagocytic systems. In these respects such studies do not relate to the conditions occurring within abscess cavities or at the site of peritoneal soiling with faecal contents.

We thank Professor K. Boddy and Mr P. O. Byrne, Regional Medical Physics Department, General Hospital, Newcastle upon Tyne, for helpful discussions, advice and provision of purpose-built rotary equipment. We are also indebted to Dr J. K. Wardle, Dr D. I. Gladstone and Miss V. M. Ions for their photographic expertise, and Miss Alison Moore for her patience in typing the manuscript. 


\section{REFERENCES}

Biggar, W. D. 1975. Phagocytosis in patients and carriers of chronic granulomatous disease. Lancet, 1, 991.

Bjornson, A. B., Altemeier, W. A. And Bjornson, H. S. 1976. Comparison of the in vitro bactericidal activity of human serum and leukocytes against Bacteroides fragilis and Fusobacterium mortiferum in aerobic and anaerobic environments. Infect. Immun., 14, 843.

BJORNSON, A. B. AND BJORNSON, H. S. 1978. Participation of immunoglobulin and the alternative complement pathway in opsonization of Bacteroides fragilis and Bacteroides thetaiotaomicron. J. infect. Dis., 138, 351 .

Casciato, D. A., Rosenblatt, J. E. Goldberg, L. S. and Bluestone, R. 1975 . In vitro interaction of Bacteroides fragilis with polymorphonuclear leukocytes and serum factors. Infect. Immun., 11, 337.

Cowan, S. T. 1974. Cowan and Steel's manual for the identification of medical bacteria, 2nd ed., Cambridge University Press, Cambridge.

Duerden, B. I., Holbrook, W. P., Collee, J. G. AND Watt, B. 1976. The characterization of clinically important gram negative anaerobic bacilli by conventional bacteriological tests. J. appl. Bact., 40, 163.

Gorbach, S. L. and Bartlett, J. G. 1974. Anaerobic infections. New Engl. J. Med., 290, 1177.

Hays, R. C. and Mandell, G. L. 1974 . $\mathrm{pO}_{2}, \mathrm{pH}$, and redox potential of experimental abscesses. Proc. Soc. exp. Biol. Med., 147, 29.

Ingham, H. R., Dutton, J., Sisson, P. R., SPrott, M. S. And Selkon, J. B. 1978. An aid to the preliminary identification of non-sporing anaerobes. J. clin. Path., 31, 806.

Ingham, H. R., Sisson, P. R., Tharagonnet, D., Selkon, J. B. and Codd, A. A. 1977. Inhibition of phagocytosis in vitro by obligate anaerobes. Lancet, 2, 1252.

Light, T. S. 1972. Standard solution for redox potential measurements. Analyt. Chem., 44, 1038.

MCRipley, R. J. AND SBARRA, A. J. 1967. Role of the phagocyte in host-parasite interactions. XI. Relationship between stimulated oxidative metabolism and hydrogen peroxide formation, and intracellular killing. J. Bact., 94, 1417.

MANDELL, G. L. 1974. Bactericidal activity of aerobic and anaerobic polymorphonuclear neutrophils. Infect. Immun., 9, 337.

Tally, F. P., Goldin, B. R., Sullivan, N., Johnston, J. and Gorbach, S. L. 1978. Antimicrobial activity of metronidazole in anaerobic bacteria. Antimicrob. Agents Chemother., 13, 460.

Tharagonnet, D., Sisson, P. R., Roxby, C. M., Ingham, H. R. and Selkon, J. B. 1977. The API ZYM system in the identification of gram-negative anaerobes. J. clin. Path., 30, 505.

Tofte, R. W., Peterson, P. K., Schmeling, D., Bracke, J., Kim, Y. and Quie, P. G. 1980. Opsinization of four Bacteroides species: role of the classical complement pathway and immunoglobulin. Infect. Immun., 27, 784.

WALDEN, W. C. AND HenTGES, D. J. 1975. Differential effects of oxygen and oxidation-reduction potential on the multiplication of three species of anaerobic intestinal bacteria. Appl. Microbiol., 30, 781.

Weinstein, W. M., Onderdonk, A. B., Bartlett, J. G., Louie, T. J. and Gorbach, S. L. 1975. Antimicrobial therapy of experimental intraabdominal sepsis. J. infect. Dis., 132, 282. 